\title{
CERISE SKY MEMORIES
}

A gift to remember.

\section{BY WENDY NIKEL}

$\mathrm{I}$ remember a childhood that didn't exist. Hot apple pies cooling on park benches. Small toes pressed into scorching white sand. Snowball fights leaving crisp, crunchy ice crusted in the collar of my coat.

A tangle of neurological connections to construct a lifetime that never was. Things that never happened. Places that don't even exist.

We whisper about these memories sometimes, Marina and me. She's the only other X3-Model left in the office. The only other employee-asset remaining from that brief phase in biotechnological progress before designers began second-guessing the cost of programming us with such concocted complexity.

"It cost ten thousand dollars per memory," Marina muses as she swirls her spoon around her yogurt. It's strawberry, as usual. She buys it by the gallon and brings it to work in dainty little Tupperware bowls that she stacks beside the white cube food-packs that the rest of us apathetically consume. I've always suspected it has to do with her childhood, but I don't ask - not in front of the others. No need to draw more attention to the fabricated pasts that they view as defects, signs of our antiquity.

"If you could buy one more," she asks, "what would you pick?"

"I don't know." I flatten my empty food-pack and keep my voice low, head down. "We ought to get back to work."

"I'd buy a birthday party," she says, staring at her spoon. "One with family. A mother. Father. Siblings."

"They wouldn't be real." Marina and I are the closest we've got to siblings - members of the same genetic batch, products of the same vats, designed for proficiency in the mind-numbing tasks of corporate sorting and filing.

Marina shrugs and licks the spoon. "At least I'd have someone to remember."

In my favourite memory, I'm sitting on a front-porch swing, my legs tucked beneath me and a book on my lap, watching a cerise sunset over a vast, windmill-dotted field. A breeze blows across my face, and I close my eyes, breathing in rich loam.

Marina says that's why I like the quiet why city life sets me on edge. A glitch, the company would call it if they knew, which is why I work so hard to keep from startling when the boss calls out my number, summoning me to his office.

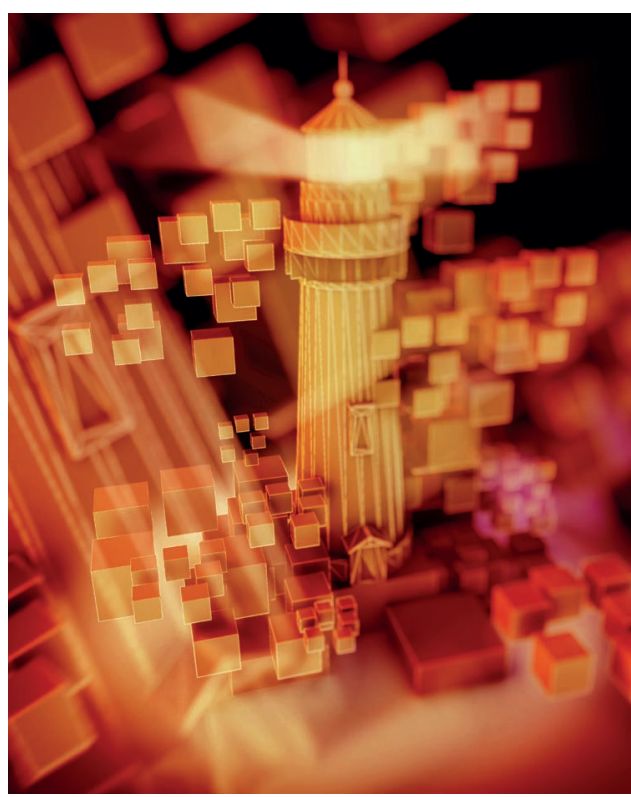

My toes press into the scorching white sand. I lick my salt-cracked lips.

A hot-dog vendor lends me his pen, and I scribble a napkin-sized sketch, but none of the beachcombers recognize the windmill field. None knows of jobs for decommissioned X3s.

The sand turns gritty. My shoulders burn. The sun dips low towards the horizon, and doubts creep in with the cold.

I shouldn't have left the city. I shouldn't have assumed that because one memory was based on fact, all of them must be real.

Yet it doesn't stop me from asking two ... four ... ten more times. It doesn't stop my tears when someone finally says, "I know where that is."

I stand on the doorstep and wring my hands, unsure what I hope for, yet hoping against hope, and when a woman in overalls and a red bandana answers, she looks just as confused as I feel.

I've never been in his office before.

It's a small room with buzzing, yellowed light. A trio of framed pictures sits upon a desk too large for the space, and one of them depicts a scene so familiar, I can't help but stare, can barely comprehend his words:

"You're being decommissioned."

"Decommissioned?" I stare not at him, but at the lighthouse in the photograph. The cliff. The waves. I can almost feel the sand in my toes, taste the salt on my lips.

"We're bringing in new X14-Models," he continues. "When you punch out today, we'll remove your chip and you'll be free to pursue other employment, no longer company responsibility."

No longer company responsibility, meaning they will no longer provide me with food, shelter, clothes. Decommissioned, meaning declared obsolete.

"Any questions?"

"Yes." I point to the picture. "Where was that taken?"

Before I punch out, I slip Marina a note that I hope makes her own decommissioning easier: They're real. I've seen it. The places from our childhood exist.

I buy a bus ticket I can't afford to a state where I've never been and hope that whoever programmed that lighthouse in my

$\rightarrow$ NATURE.COM Follow Futures:

y @NatureFutures

$f$ go.nature.com/mtoodm mind was drawing from their own experiences, and that the farmhouse will be nearby.
"Do you live here?” I ask. "That is ... have you lived here long?"

"Grew up here. You're an X3-Model."

"Yes."

"I worked on your kind, back in the day."

"In memory modifications?"

She raises a greying eyebrow. "How'd you know?"

I want to ask about the porch swing, about the book, about the sunset itself - things so important she infused them into her work, leaving a sliver of herself within me.

I want to ask how she ended up here - if, when the memory mods were discontinued, she became obsolete, too. No longer company responsibility.

I want to ask if she needs anything sorted or filed. I want to ask about the dirt on her knees. I want to ask about snowball fights and apple pie and whether the city noise makes her nervous, too, and if that's why she returned to this quiet place with gentle breezes that smell of loam.

But she's the one to make the first move, to nudge the screen door open. "Why don't you join me on the porch for some tea? It seems we might have some things in common."

I follow, in steps of hope, as a cerise sunset lights the sky.

Wendy Nikel is a speculative fiction author with a degree in elementary education, a fondness for road trips and a terrible habit of forgetting where she's left her cup of tea. For more info, visit wendynikel.com. 